\title{
A short review on the comparison of consultation systems and tools in the emergency department practice: Tele-consultation
}

\section{Acill servis pratiğindeki konsülltasyon sistemleri ve araçlarının kıyaslanması üzerine kısa bir derleme: Tele- konsültasyon}

\author{
Sevilay Vural ${ }^{1}$, Hayri Ramadan ${ }^{2}$
}

Acil Tip Anabilim Dalı. Yozgat Bozok Uygulama ve Arastırma Hastanesi, Bozok Üniversitesi, Yozgat, Türkiye

${ }^{2}$ Acil Servisi, Ankara Eğitim ve Araştırma Hastanesi, Ankara/Türkiye

Corresponding author: Sevilay Vural, MD., Acil Tıp Anabilim Dalı, Yozgat Bozok Uygulama ve Araştırma Hastanesi, Bozok Üniversitesi, Yozgat, Türkiye

E-mail: sevilayvural@yahoo.com

Received/Accepted: May 21,2019/May 24, 2019

Conflict of interest: There is not a conflict of interest.

\section{SUMMARY}

Emergency department (ED) consultation is an important part of acute patient care and one of the major determinants of ED length of stay (LOS). ED consultations between physicians who may not be in the same location frequently, require a tool to reach out one another and communicate. This paper reviews the historical change and development of consultation tools. The literature on ED consultation methods have been accumulating for the last two decades as the diversity of these methods has increased with technology. Most of the studies demonstrate that high tech systems are useful and safe to reach the consultant and share medical information flow. Moreover, the future of the area offers new developments regarding consultation tools that are hard to imagine yet like augmented reality.

Keywords: Consultation, teleconsultation, emergency medicine, length of stay, technology.

\author{
(iD) Sevilay Vural \\ (D) Hayri Ramadan
}

ORCID IDs of the authors: S.V. 0000-0002-1722-7987 H.R. 0000-0002-5018-152X

\section{ÖZET}

Acil servis (AS) konsültasyonu, akut hasta bakımının önemli bir parçasıdır ve AS'de kalma süresinin (KS) ana belirleyicilerinden biridir. Aynı alanda bulunmayan hekimler arasındaki AS konsültasyonları, sıklıkla birbirlerine ulaşmak ve iletişim kurmak için bir araç gerektirmektedir. Bu makale konsültasyon araçlarının tarihsel değişimini ve gelişimini gözden geçirmektedir. Son 20 yılda AS konsültasyon yöntemleri ile ilgili yöntemlerin çeşitliliği arttıkça bu alandaki literatür de birikmeye başlamıştır. Çalışmaların çoğu, yüksek teknoloji sistemlerinin konsültana ulaşmak ve tıbbi bilgi akışını paylaşmak için yararlı ve güvenli olduğunu göstermektedir. Dahası, alanın geleceği, artırılmış gerçeklik gibi hayal edilmesi zor olan konsültasyon araçları ile ilgili yeni gelişmeler vadetmektedir.

Anahtar sözcükler: Konsültasyon, tele-konsültasyon, acil servis, kalış süresi, teknoloji 


\section{INTRODUCTION}

Emergency departments (EDs) are 24-hour emergency care points of health care. They have to serve a broad spectrum of patients who need acute diagnosis, treatment, and/or interventions. It is inevitable that all these processes take a certain time to implement, termed as the length of stay (LOS) ${ }^{1,2}$. ED LOS correlates with crowing and complication rate in EDs. There is a growing literature which describes ED crowding and LOS determinants. Moreover, studies suggest that there is a vicious cycle between ED crowding and LOS 3-5. All the studies and efforts aim to improve safe and effective patient throughput in the EDs by breaking this vicious cycle.

LOS is affected by a variety of factors including demographic characteristics, aging population, high incidence of chronic conditions, avoidance of malpractice, high level of testing, consultation, imaging studies, as well as inappropriate use of levels of the health system and clinical practice of EDs (i.e., triage systems, facility feasibilities, medical staff competency, and organization) ${ }^{1,6,7}$. Among these factors, human factor-containing variables seem to be the hardest to fix like the consultation process.

Consultation is sometimes described as a patient's request for medical advice from a physician, but we will focus on the physician to physician consultation and the tools used during the communication. Emergency consultation can be described as the request of an emergency physician (EP) from a relevant and related department for the assistance, cooperation and taking over care of the patient on issues such as admission, diagnosis, discharge, follow-up, and intervention ${ }^{8}$. Consulting circle consisting of at least two physicians (consultation requester and consultant) and one patient. It is a human-centered profession. And considering the working conditions of the EDs, it may turn to a challenging, exhausting, and a certain timerequiring activity for each side of this relationship.

Besides the human factors, the consultation process necessitates technical communication tool infrastructure. Physicians have always used some forms of communication devices for consulting one another (the common tools for the consultation that has been used in the literature are listed in Table 1). The forms and types of communication tools and devices have transformed with the effect of technology, and this transformation is even more apparent in the age of informatics we live in.
Table 1: The common tools for the consultation

\begin{tabular}{l}
\hline Consultation tools \\
\hline Letter \\
\hline Telephone (domestic lines) \\
\hline Pager \\
\hline Fax \\
\hline Computer-based consultation systems \\
\hline Mobile phone \\
\hline Smartphone \\
\hline Web-based medical record programs
\end{tabular}

The physicians may need a second opinion in practice. It is not hard to imagine junior physicians consulting Hippocrates in his medical school/hospital on the Greek island of Cos around the 4. century BC. That can also be described as the first consultation performance in the history of medicine. Consultations between physicians have continued as a face-to-face interaction for centuries, and this has been the backbone of almost all consultation types. After the medieval ages, discoveries and technological developments have followed one other. For example, when the use of letter for long distance communication has gained popularity, this practice has manifested itself in the medical world, as well. Medical consultation by letter was a quite popular practice during the 18th and 19th centuries 9 . However, it is not an emergency consulting option due to limited and time-requiring features.

With the advent of radio wave use, radio channels have become the major communication tool worldwide. The radio announcements have been used to reach emergent help or professional skills in the cases of wars or catastrophes despite limited use for medical purposes. Although no known study exists focusing on the use of radio for consultation, short and long-distance walkietalkies are still used for consultations of the patients in war areas.

Invented in 1876 , the telephone has gained a widespread use across the world in a short span of time. Ironically, one of the first recorded telephone calls by its inventor, Alexander Graham Bell, was about his medical help need after injuring himself with sulphuric acid ${ }^{10}$. By the 1970s, the telephone has become a fixture in hospitals as well as homes. For the context of 
hospitals, the popularity of telephones stems from providing an opportunity for instant, real-time voice communication among physicians without leaving the reference area. Nowadays, up to a quarter of all clinical consultations occur by phone ${ }^{11}$. Despite its disadvantages, such as lack of face-to-face interaction, the telephone has eliminated the spatial problems such as local and global location limits. Fax technology, a related technology of telecommunication, has been used for the transmission of medical text and graphics data between two locations via telephone lines ${ }^{12}$, in addition to medication order and pharmacy order systems, main areas of use for fax technology. The fax is not the only alternative use of telephone lines. Pager devices have been put forward as "cordless telephones," which can receive a call and/or text message from a telephone call. The first patented pager was invented in 1949, and it became a popular tool of communication among public and physicians between 1980-2000. For medical use, pagers enabled users to see caller ID and take action due to the caller department.

By the 1980s, the computer era has begun, and since then, we have been witnessing the progress and development in computer technology. Needless to say, computer-based consultation systems have gained widespread use, as well. The fixed telephones, pagers, computers, laptops have got into the market and started to spread up all over the world by the millennial years. Of course, the most prominent change has been brought about with the advent of the internet, as well as the mobile and smartphones during the last 20 years. The medical staff has got their portable personal technologic devices as the rest of the world have done. It is more practical for physicians to use personal mobile/smartphones instead of fixed telephones or pager devices that were previously owned by the hospital. In terms of communication with smartphones, very significant improvements have been achieved.

Telemedicine is a relatively new concept, and in the world of internet, it develops with speed of light. Teleconsultation can be considered as one of the branches of telemedicine ${ }^{13}$. Thanks to computers, smartphones, and tablets, physicians who previously communicated with the other physicians only via an audible communication tool have become able to send the laboratory results, images of diagnostic techniques, videos, series of the images, and even show the patient's own or related pathology with video conversation. Moreover, the new tools help physicians to search for answers about the problems of concerning patients in medical forums, portals, medical websites, instant medical chat groups, medical applications, and e-books. Even robotic surgical devices can be considered as a way of consultation when it is operated over long distances via internet connection. Augmented Reality (AR) as a consultation tool seems to have amazing advances for the future. AR is speculated about its potential to allow medical knowledge, skills, and expertise to be shared instantly and remotely.

Although a wide range of telecommunication systems exist, all of them are not suitable for emergency consultation due to some limitations. Within the context of EDs, actively used ones are domestic telephone lines, pagers, computer-based systems, mobile, and smartphones. Moreover, despite the long history of telecommunication for consultation, the literature in this topic has been a limited one until the 2000s. Most of the studies conducted in this topic have focused on the efficacy assessment of various communication systems and tools as well as comparisons between them. For example, Forsblom et al. found that bedside consultation is superior to telephone consultation ${ }^{14}$. As for the assessment of efficacy, Cho et al. found that the use of a computerized consultation system decreases ED LOS in comparison to mobile phones ${ }^{15}$. Several studies focused on triage outcomes, the effects on patient subgroups, and the comparison between telephone and pager systems ${ }^{8,}{ }^{16-21}$. The findings are somewhat controversial, but the general trend displays that pager systems have the ability to decrease LOS, although telephone consultation is sufficient most of the times. Although there have been many publications on LOS in ED and ED crowding, studies comparing the efficiency of various consultation tools during the consultation process have increased only with the use of mobile and smartphones. Most of these studies show that these high tech systems are useful and safe to reach the consultant and share medical information flow ${ }^{22-30}$.

\section{CONCLUSION}

The main determinants of consultation tool power are feasibility, size of the device, boosting of faceto-face interaction, transmittable amount of patient data, data type, user-friendly interface, and portability. Every consultation tool has advantages and disadvantages, but we can conclude that the consultation process is evolving with technological advancements. 


\section{REFERENCES}

1. Chaou $\mathrm{CH}$, Chiu TF, Yen $\mathrm{AM}, \mathrm{Ng} \mathrm{CJ}$, Chen HH. Analyzing Factors Affecting Emergency Department Length of StayUsing a Competing Risk-accelerated Failure Time Model. Medicine (Baltimore). 2016;95(14):e3263. DOI:10.1097/MD.0000000000003263. Pubmed PMID:27057879.

2. Yoon, P, Steiner, IP, Reinhardt, G. Analysis of factors influencing the length of stay in the emergency department. CJEM. 2003;5:155. DOI:10.1017/S1481803500006539. Pubmed PMID:17472779.

3. Pines JM, Prabhu A, Hilton JA, Hollander JE, Datner EM. The effect of emergency department crowding on length of stay and medication treatment times in discharged patients with acute asthma. Acad Emerg Med. 2010;17:834-839. DOI:10.1111/j.1553-2712.2010.00780.x. Pubmed PMID:20670320.

4. McCarthy ML, Zeger SL, Ding R, Levin SR, Desmond JS, Lee J, Aronsky D. Crowding delays treatment and lengthens emergency department length of stay, even among high-acuity patients. Ann Emerg Med. 2009 Oct;54(4):492-503.e4. DOI:10.1016/j.annemergmed.2009.03.00 6. Pubmed PMID: 19423188.

5. Bernstein, S, Aronsky, D, Duseja, R, Epstein S, Handel D, Hwang U et al. The effect of emergency department crowding on clinically oriented outcomes. Acad. Emerg. Med. 2009;16:1- 10. DOI:10.1111/j.1553-2712.2008.00295.x. Pubmed PMID:19007346.

6. Kreindler SA, Cui Y, Metge CJ, Raynard M. Patient characteristics associated with longer emergency department stay: a rapid review. Emerg Med J. 2016 Mar;33(3):194-9. DOI:10.1136/emermed2015-204913. Pubmed PMID:26341654.

7. Richardson, DB. Increase in patient mortality at 10 days associated with emergency department overcrowding. Med. J. A. 2006;184:213-216. DOI: $10.5694 / \mathrm{j} .1326-$

5377.2006.tb00204.x.

Pubmed PMID:16515430.

8. Vural S, Icme F, Kavakli HS, Tanriverdi F, Karakayali O. A comparison study on the effectiveness of pager and telephone systems during emergency department consultations and length of stay of consulted emergency department patients. Turk J Clin Lab 2019; 1: 12-17. DOI:10.18663/tjcl.336946.

9. Pilloud S, Hächler S, Barras V. [Medical consultation by letter in the 18th century]. Gesnerus. 2004;61(3-4):232-53. Pubmed PMID:15889706.

10. Aronson SH. The Lancet on the telephone 1876-1975. Med Hut. 1977; 21:60-87.

11. Vaona A, Pappas Y, Grewal RS, Ajaz M, Majeed A, Car J. Training interventions for improving telephone consultation skills in clinicians. Cochrane Database Syst Rev. 2017(Jan);1:CD010034. DOI:10.1002/14651858.CD010034.pub2. Pubmed PMID:28052316.

12. Peterson AM. Facsimile (fax) technology. Hosp Pharm. 1991;26(2):110-2,1156,124. Pubmed PMID:10109219.

13. Gattu R, Teshome G, Lichenstein R. Telemedicine Applications for the Pediatric Emergency Medicine: A Review of the Current Literature. Pediatr Emerg Care. 2016 Feb;32(2):123-30. DOI:10.1097/PEC.0000000000000712. Pubmed PMID:26835573.

14. Forsblom E, Ruotsalainen E, Ollgren J, Järvinen A. Telephone consultation cannot replace bedside infectious disease consultation in the management of Staphylococcus aureus Bacteremia. Clin Infect Dis. 2013 Feb;56(4):527-35. DOI:10.1093/cid/cis889. Pubmed PMID:23087397.

15. Cho SJ, Jeong J. Decreased emergency department length of stay by application of a computerized consultation management system. Acad Emerg Med. 2011 Apr;18(4):398-402. DOI: 10.1111 /j.1553-2712.2011.01039.x. Pubmed PMID:21496143.

16. Perrin EC, Goodman HC. Telephone management of acute paediatric illnesses. N Engl J Med. 1978 Jan 19;298(3):130-5. DOI:10.1056/NEJM197801192980304. Pubmed PMID:619242.

17. Pimentel LE, Yennurajalingam $S$, Chisholm G, Edwards T, Guerra-Sanchez M, De La Cruz M et al. The frequency 
and factors associated with the use of a dedicated Supportive Care Center Telephone Triaging Program in patients with advanced cancer at a comprehensive cancer centre. J Pain Symptom Manage. 2015 May;49(5):939-44. DOI:10.1016/j. jpainsymman.2014.10.020. Pubmed PMID:25666520.

18. Car J, Sheikh A. Telephone consultations. BMJ. 2003 May 3;326(7396):966-9. DOI:10.1136/bmj.326.7396.966. Pubmed PMID:12727771.

19. Isaacman DJ, Verdile VP, Kohen FP, Verdile LA. Pediatric telephone advice in the emergency department: results of amock scenario. Pediatrics.1992;89(1):35-9. Pubmed PMID: 1728017.

20. Patel A, Dale J, Crouch R. Satisfaction with telephone advice from an accident and emergency department: identifying areas for service improvement. Qual Health Care. 1997 Sep;6(3):140-5. DOI:10.1136/qshc.6.3.140. Pubmed PMID:10173771.

21. Patel H, Patel M, Car J. Telephone consultations in general practice: aAreas for improvement. $\mathrm{J}$ Telemed Telecare. 2005;11(5):265-6.

DOI: $10.1258 / 1357633054471876$.

Pubmed PMID:16035971.

22. Liddy, C., Moroz, I., Mihan, A., Nawar, N. \& Keely, E. A systematic review of asynchronous, provider-to-provider, electronic consultation services to improve access to specialty care available worldwide. Telemed J E Health. 2019 Mar;25(3):184-198. DOI:10.1089/tmj.2018.0005. Pubmed PMID:29927711.

23. Fang JL, Collura CA, Johnson RV, Asay GF, Carey WA, Derleth DP et al. Emergency Video Telemedicine Consultation for Newborn Resuscitations: The Mayo Clinic Experience. Mayo Clin Proc. 2016 Dec;91(12):1735-1743.

DOI:10.1016/j.mayocp.2016.08.006. Pubmed PMID:27887680.

24. Paik AM, Granick MS, Scott S. Plastic surgery telehealth consultation expedites Emergency Department treatment. J Telemed Telecare. 2017 Feb;23(2):321-
327. DOI:10.1177/1357633X16639459. Pubmed PMID:27056907.

25. Finnane AR, Siller G, Soyer HP. Teledermatologists' management of emergency skin conditions. Med J Aust. 2015 Oct 5;203(7):286. DOI: 10.5694/mja15.00362. Pubmed PMID: 26424060 .

26. Ouellette L, VanDePol E, Chassee T, Tavares E, Flannigan M, Jones J. Emergency department electrocardiogram images sent through the mobile phone: Feasibility and accuracy. Am J Emerg Med. 2018 Apr;36(4):731-732.

DOI:10.1016/j.ajem.2017.09.010. Pubmed PMID:28917438.

27. Boissin C, Blom L, Wallis L, Laflamme L. Image-based teleconsultation using smartphones or tablets: qualitative assessment of medical experts. Emerg Med J. 2017 Feb;34(2):95-99. DOI:10.1136/emermed-2015-205258. Pubmed PMID:27707791.

28. Atherton $\mathrm{H}$, Brant $\mathrm{H}$, Ziebland $\mathrm{S}$, Bikker A, Campbell J, Gibson A et al. Alternatives to the face-to-face consultation in general practice: focused ethnographic case study. Br J Gen Pract. 2018 Apr;68(669):e293-e300. DOI: 10.3310/hsdr06200. Pubmed PMID: 29889485.

29. Hasselberg $M$, Wallis $L$, Blessing $P$, Laflamme L. A smartphone-based consultation system for acute burns methodological challenges related to follow-up of the system. Glob Health Action. 2017 Jun;10(sup3):1328168. DOI:10.1080/16549716.2017.1328168. Pubmed PMID:28838311.

30. Liddy C, Drosinis P, Keely E. Electronic consultation systems: worldwide prevalence and their impact on patient care-a systematic review. Fam Pract. 2016 Jun;33(3):274-85. DOI:10.1093/ fampra/cmw024. Pubmed PMID: 27075028. 